locality and Spain. On the last afternoon of the fortnight, Convoluta Roscoffensis was noted, an extraordinary example of symbiosis between a worm and an alga. Of bird-life, Mr. Le Maître led a party to the cliffs at Crabbe, to photograph the herringgullery there, and the Rev. Pere Burdos led a party to the Pinnacle, a rock $200 \mathrm{ft}$. above sea-level near Plemont, where the peregrine falcon, raven, puffin and nesting guillemots, razorbills and oyster-catchers were seen. The granites in which Jersey is so rich interested the geologists, and while studying a quarry near Gorey Castle the rare hyssop-leaved loosestrife plant was noted. The first meeting of the London branch of the B.E.N.A. will be held at the Furnival Hall, Furnival Street, on October 16, when Mr. J. Ramsbottom will lecture on "Moulds and Mushrooms".

\section{Technical College Buildings}

IT is little less than astonishing that a country like Great Britain, which has been the pioneer in scientific work and retained so high a standard of scientific achievement, should have such a paucity of literature dealing with material needs in the matter of buildings and equipment necessary for its field of activity. Books dealing with laboratories can be counted on the fingers, while for any wide general account of technical institutions dealing with the application of science to the trades, it is necessary to go back nearly half a century. The report, published at the expense of the Carnegie United Kingdom Trust, by a Joint Committee of the Association of Technical Institutions, the Association of Principals of Technical Institutions with representatives of the Royal Institute of British Architects and the Institute of Builders and a member of the staff of the Board of Education is therefore to be specially welcomed, particularly at the present time when the demands for buildings for technical education are so marked (London : Associa. tion of Technical Institutions and the Association of Principals of Technical Institutions, 1935 . 3s.) The volume, consisting of some 150 quarto pages including plans and illustrations, is the work of a representative committee the personnel of which is sufficient evidence of authority. 'The opening two chapters deal with general requirements including service supplies and accommodation, and these are followed by concise articles on the special needs of specific subjects, some twenty in all, embracing such fields as leather industries, printing and textiles in addition to the more generally taught trade principles. These chapters, which occupy the bulk of the volume, have been compiled by panels of experts intimately associated with the required tuition. The brochure concludes with two chapters illustrated with plans and photographs of recent British and Continental examples of buildings, and should be of great value to all concerned with the development and execution of schemes for technical education.

\section{Temperament in Industry}

THE effects of having the wrong type of persons in positions of authority were discussed by Dr. May
Smith, senior investigator to the Industrial Health Research Board, in a lecture on May 27 forming part of a course on the temperamental factor in industry arranged by the National Institute of Industrial Psychology. She said that it was not uncommon to find that a high rate of sickness absences was the result of having a supervisor with the wrong temperament for his job. Sickness is also frequently ascribed to overwork, but overwork itself is often the result of having to deal with the unreasonable demands of heads who are irrational and lack emotional balance. After dealing with various temperamental types who cause trouble when they are in important positions, Dr. May Smith outlined the attributes of a good head. Assuming that he has the necessary intellectual powers and technical knowledge, the first requirement is a sense of justice - a capacity for asking, not "Am I receiving justice ?" but "Am I giving it ?" A good head must create the knowledge that everyone under him will receive fair treatment. A second quality is vitality, explaining that she meant not physical exuberance, which is often exhausting to subordinates, but the controlled energy that inspires them. "The 'Weary Willy' and the 'Streak of Misery'," she said, "should have no place at the head." The next requisite is the ability to regard people and things dispassionately, to see them as they really are, and not merely as they happen to appeal to the man himself. A sense of humour is the next requisite, to prevent the head taking himself too seriously. Finally, the good head must be able to rule without straining his powers on one hand or shirking responsibility on the other. Tem. peramental factors in industry do not receive sufficient attention in Great Britain, and it is a pity employers and departmental managers do not receive training in handling personalities. 'Nagging' might well be made a capital offence !

\section{The Government Laboratory}

Few, apart from those who study the annual report of the Government Chemist, are well acquainted with the character and volume of the work which is carried out at the Government Laboratory. A detailed and illustrated account of the activities of this laboratory has recently been published in the Chemist and Druggist ; since much of the informa. tion which relates to processes and figures has been supplied to the author, the article can be accepted as an accurate and fully informed review. The Department of the Government Chemist, in its capacity of a protector of the revenue, undertakes the routine analysis of large numbers of samples of dutiable goods, handling, for example, some 5,000 samples of tobacco every week. As a public servant assisting in suppressing adulteration, it acts as a referee when reports of public analysts are challenged. The samples concerned have frequently undergone changes by the time they reach the laboratory-this applies particularly to samples of milk-so that the necessary analytical procedure is much more elaborate than normally. Such considerations involve a good deal of research, leading to the working out of satisfactory analytical methods. Another function 